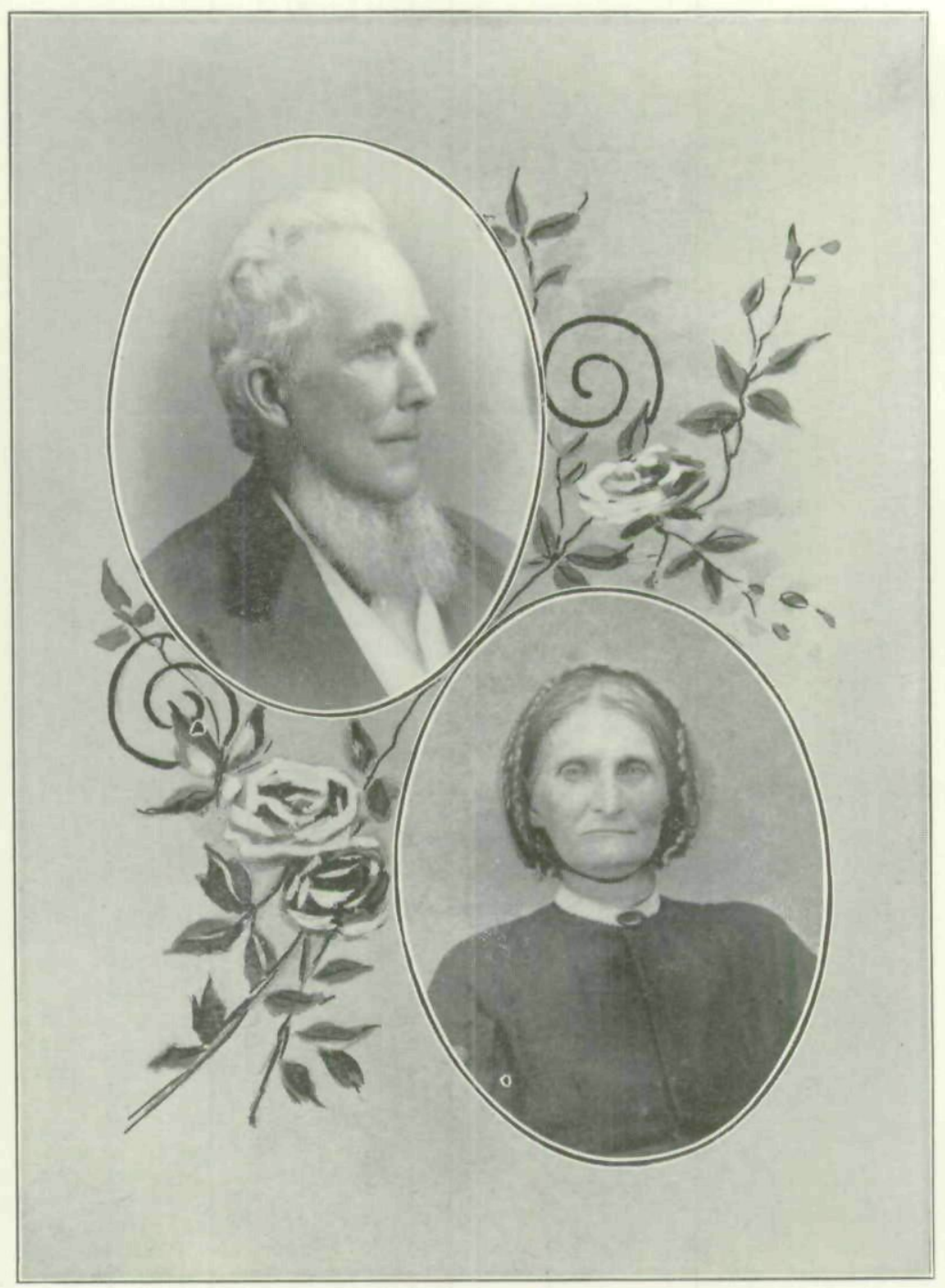

MR. AND MRS. DAVID SEWARD HAHN,

Pioneer settlers of Linn County. Iowa. 


\section{THE EARLIEST SETTLERS OF LINN COUNTY.}

BY JOHN J. DANIELS.

The writer feels that the early history of Iowa would be incomplete, when impartially written, if two early settlers, Daniel Seward Hahn and his wife, Permelia (Epperson) Hahn, did not receive the appreciative and grateful tribute of respect which is justly due to their memory. They were early pioneers and first settlers in Franklin township, Linn county, Iowa, and are now believed to have been the first in Linn county. This honor for many years was awarded to Edward M. Crow, who, no doubt, honestly believed that he was the first settler, for the home of the one was about twelve or fourteen miles from the other, and the early settlers were too busily engaged with their own personal affairs to search out the locality of others.

An investigation of this subject has been made within the past five years, which proves, as I shall endeavor to show, that Mr. Hahn preceded Mr. Crow by several months, and that Mrs. Hahn was the first white woman who became a permanent settler in the county. I visited Mr. Hahn at his home near Mt. Vernon, Iowa, on the 13th of September, 1894, under the impression that he was the oldest and earliest settler of the county living, and I will give his own statement in the following words:

My brother-in-law, Charles Moberly, and I came to Linn county, Iowa, in the spring of 1837 , made a claim and built a cabin on it up to the square; did some breaking, and in the latter part of August, 1837, removed my wife and five children from Mercer county, Illinois, into this same cabin. Mrs. Hahn was the only help I had in putting up the weight poles on the roof, which was covered with clapboards. At that time there was no other house or settler in the township or county to my knowledge.

It is my aim to give the truth, only, for the benefit of posterity, having no desire or wish to lessen the just and merited honor of any old settler, and entertaining no personal prejudice against either one. Therefore, I ask that 
the reader of these pages will render judgment in accordance with the preponderance of evidence herein presented, which evidence depends largely upon the memory and the surrounding circumstances of those claiming priority.

It is a matter of regret that, while the early settlers were laying the foundation stones for future historians to build upon, such a limited number of the early incidents were reduced to writing. The one who now undertakes the task of presenting a truthful history of important events which transpired more than half a century ago, is at times compelled to give the nearest approximate date obtainable. The accumulated evidence clearly disposes of the doubt, as to which of the two men, Hahn or Crow, was the first person to make a claim, and erect a cabin in Linn county.

I now introduce the evidence in behalf of Mr. Crow's claim, as published in his obituary in The Cedar Rapids Weekly Gazette, of August 9, 1894. From its resemblance in phraseology, I judge that it was largely copied from a sketch in the "History of Linn County," published in 1878, which was dictated personally by himself to the writer of that history. (See page 336, "History of Linn Co."). The statement is as follows:

He left Kane county, Illinois June 4th, and on July 4, 1837, laid claim to Sections 13 and 14, now in Brown township; staid four days in the county and then returned to Fox River, Illinois; and a short time afterwards in company with James Dawson and his brother, Garrison Crow, purchased six yoke of oxen and made preparation to return to Iowa. The little wagon train left Fox River the latter part of August and reached Linn county September 5,1837. . . . Then the three erected a shanty near a small stream, afterwards named Crow Creek.

The evidence in Mr. Crow's behalf is somewhat conflicting, as the same history of Linn county on page 334 reads thus: "Late in August, 1837, Edward M. and Garrison Crow, his brother, and James Dawson, came to Linn county, this time prepared to begin work in earnest. . . . They put up a cabin September 5, 1837." On page 815, the history states: "In the fall of 1838 he (Mr. Crow) sold his 
claim to Olmsted \& Parker, and went to Indiana and spent the winter in' going to school, but the following spring (1839) he returned to Linn county, and settled where he now lives." When Mr. Crow located in Linn county he was a single man, and was not married until November 14, 1839. Therefore, Mr. Hahn and wife with their five children constituted the first family in the county.

Hosea W. Gray, one of the historians of Linn county, for the Iowa Gazetteer, says: "John Mann [should have been Jacob Mann] was the first settler, coming in February, 1838." Charles C. Haskin, of Franklin township, made the claim of being the first settler in the county, but this is not supported by any outside evidence or circumstance. The three aspirants Mann, Crow and Haskin, were single men when they came and for several years afterward, and their permanent residence at first was only long enough within the year to secure their claims.

When I visited Mr. Hahn, then past his eighty-sixth year, I was surprised to find him enjoying such good health. His memory was clear and retentive, and he manifested the same degree of vivacity which he did in his earlier years. He was a free and easy conversationalist, naturally witty and always jovial in his disposition, and he enjoyed a good joke when told, or even perpetrated upon himself. As an illustration of this I will give in his own words one of the stories which he frequently told:

One of my wild pranks was played while with Capt. Ashton, when on our way to Fort Dearborn, and it eame very near costing me my life. Ashton's company was enlisted at Crawfordsville, Indiana, to serve in the Black Hawk war, and started from there for Fort Dearborn (now the city of Chicago). As a matter of precaution against any sudden surprise by Indians, Ashton selected five men and myself to act as scouts in advance of the main company. After reaching the vicinity of the Indian haunts, I fancied that to play Indian would test the nerve and bravery of the men. I got behind a tree near the roadside, and presented enough of my person to be discovered. Reason Goodwin was then in advance of the company, and discovering what he supposed was an Indian, ran back and reported it to the rest. The Captain hurriedly formed his men in liue, and pressed 
forward, expecting to find the enemy near, or ambushed in his front. While the men were steadily advancing to my right and left, I soon realized that my safety depended upon making myself known before being fired upon. I accomplished this by placing my hat on a stick and holding it out beyond the tree. Ashton soon discovered the hat, and my perilous situation, and restrained his men from firing. After this incident I was called Blackhawk by my comrades. The noted Chieftain for whom I received this appellation was captured before our arrival at the Fort, and while we were at, or in the vicinity of, Beaver Lake. I had no desire to play Indian again, for the anticipated joke was played at my expense, and was more hazardous than fighting Indians.

Daniel Seward Hahn was.born in Butler county, Ohio, June 9, 1808, and died January 9, 1899, at the home of his daughter, Mrs. Permelia A. Armstrong, near Mt. Vernon, Linn county, at the advanced age of ninety years and seren months. He came of good ancestry, being related on the maternal side to the Hon. William H. Seward, who was by blood his first cousin. His father, Joseph Hahn, was a native of Pennsylvania, and his paternal grandfather at one time owned the site of the present populous city of Cincinnati. He was killed by the Indians while at North Bend, Ohio, for the purpose of selling a tract of land to aid in paying a balance that he owed on the site of Cincinnati. He was the first man who removed his family to Fort Washington, now Cincinnati.

Mr. Hahn was descended from patriotic ancestry; his grandfather was a soldier in the Revolutionary war, his father in the war of 1812 , and he himself was a member of Capt. Ashton's company of Indiana Volunteer Infantry and was in actual service in the Black Hawk war. The patriotic blood in the Hahn family has coursed its way unimpaired through the veins of five generations, and before Mr. Hahn's death he had the pleasure of knowing that five grandsons were serving in the Spanish war. Three sons of John F. Hahn, to wit: Frank K. Hahn, first sergeant of Company C, 49th Iowa Volunteer Infantry, Guy Hahn, corporal of the same company and regiment, and John C. Hahn, a member of Captain George Bever's Light Artillery Company, all of 
Cedar Rapids, Iowa; Elias E. Hahn's son Victor, and Claud, son of Daniel Hahn, Jr., are both members of Company E, 49th Iowa Volunteer Infantry.

Mr. Hahn's mother died when he was five years of age, and when twelve the family removed to Indiana, where he attained his majority, and during the winter months acquired a common school education. On November 29, 1829, he was married to Miss Permelia Epperson, and shortly afterwards leased a large tract of land in Montgomery county, Indiana, where he remained until 1834. In this year he removed his family to Henderson's Grove, Illinois, remaining there until the spring of 1837 , when in company with his brother-in-law Charles Moberly, he came to Cedar county, Iowa, and, as previously stated, to Linn county the same spring. $\mathrm{He}$ made a claim, did some breaking, built a cabin in part, and in August of 1837 removed his wife and children into this cabin and they became permanent settlers of the new Territory of Iowa.

Mrs. Permelia (Epperson) Hahn was born near Nashville, Tennessee, on the 29th of November, 1804, and in early life, with her parents, removed to Kentucky and subsequently to Indiana, where she resided until her marriage to Mr. Hahn. To this union eleven children were born. Lemuel died in early childhood; Susannah married J. T. West and died several years ago; Charles E. married Almira Wolf and resides in Johnson county, Iowa; Joseph married Susan Slater, removed to Osborn county, Kansas, and became sheriff of that county; Daniel, Jr., married Eliza Tyson and resides near Mt. Vernon, Iowa; Sarah married William Murray and resides in California; Mary E. married James P. Rose, who died while serving in the union army; she subsequently married E. Haley and resides near Mt. Vernon; Lydia J. married George A. Johns, and resides in Mt. Vernon; Elias E. married his second cousin, Miss Joanna Hahn, of Illinois and resides on the old homestead; Permelia married Thomas J. Armstrong, and she and her 
two sons reside on a part of the old homestead; John F. married Lizzie Kurtz, and resides in West Cedar Rapids.

Mrs. Hahn died at her home on the 16th of November, 1881, lacking fourteen days of completing her seventyseventh year, and left surviving her a husband and nine children. She was a kind and sympathetic mother, intelligent, industrious and frugal, and assisted largely in accumulating an ample competence for the family. She had a smile for the child, a tear for the afflicted, bread for the hungry, and a willing hand for the sick who required her aid, and as a skillful practitioner in the line of obstetrics, her services were frequently required at the homes of the new settlers. She will ever be remembered with affection by the family and by those who settled in the county many years ago, and is justly entitled to the honor of being the first white female resident of the county.

Mr. Hahn's homestead originally embraced 280 acres, including prairie and timber land, and he remained on this first home from 1837 until his death, making a continuous residence of almost sixty-two years on the same farm. His tastes were for a quiet life, and the occupations of a farmer, which in his opinion to be made successful must be permanently followed with a life of patient toil. When he and his wife settled on their claim they had five children and but few worldly goods, and according to his own statement, "only twenty-five cents in money," but plenty of energy and pluck, to withstand the privations incident to pioneer life. By patient industry and economy they managed in the course of a few years to purchase the present homestead, which at this time is as fine and valuable a tract of land as any in Franklin township, though embracing only about 217 acres of the original purchase.

There were but few mills, if any, in Iowa in 1837, and what breadstuff was used had to be hauled by ox teams into the country from Illinois or trading posts along the Mississippi river; and the many modern improvements we enjoy 
to-day were not even thought of by the early pioneers. Mr. Hahn's abilities were above the average, and one of his prominent traits of character was his great fidelity to friends, which he manifested throughout his entire life. According to his statement, his first vote was cast for Andrew Jackson for his second term of the presidency, and throughout his remaining years he was an ardent advocate of Jacksonian democracy. In his early manhood he became a member of the old school Baptists, and was a firm believer in predestination, though by no means pessimistic. He always saw the bright and promising side of surrounding conditions, never becoming gloomy or despondent over the trials and vicissitudes of life. He was gifted with good business judgment and reasoning powers, and as a ready debater and defender of the principles of his political or religious views, had few equals. He loved to talk on the great doctrines of election and predestination, delighting in the sermons of $\mathrm{Mr}$. Spurgeon who made these beliefs so practical and comforting to his followers. He was patriotic, humane and benevolent, a friend to the poor and needy; throughout his life he was loyal to his church, and his last words were "I know I have a Saviour; my hope is well founded; my faith is built upon a firm foundation."

To the early pioneers the landscapes and the scenery of Iowa were ever grand and beautiful; the shady groves, the vast stretches of undulating prairies so profusely bedecked in springtime, with the richest and choicest flowers in all their native beauty, the many rivers, waterfalls, and crystal fountains, at first sight, were fascinating and inviting to the eyes of the beholders, especially to those in search of new homes. They fully realized that nature had done her part with a bountiful and outstretched hand, and had clothed the prairies with an abundant supply of verdure, which would afford food in summer and hay in winter for the cattle so largely used by the first settlers. Nor was this all, for the new Territory was abundantly supplied with wild animals, 
fowl and fish, which often-times furnished palatable meals for the tired and weary hunter or fisherman and his family. The skins of the furred animals served a much needed purpose in supplying materials for caps, mittens and other articles of clothing, The early settler was only regarded as within the limits of fashion when dressed in buckskin coat or trousers with coonskin cap.

There was a certain class of personal belongings considered almost indispensable with the early settlers; such as good guns, hunting-pouches, powder-horns, butcher-knives, and several faithful, trusty dogs, whose sagacity and unerring scent, when in pursuit of game, seldom deceived their master. "Sancho" and "Blucher" soon learned that when the chase was successful it gave them a rare meal.

I should fail to do justice to this once new and inviting Territory without mentioning the fact that all the timbered portions seemed to be one general apiary, affording vast quantities of choice honey to the bee-hunter, and it was not an unusual thing to see from half to a full barrel of honey and comb gathered by a family. Its plentifulness almost destroyed the home-market, for nearly every settler was well supplied or had dozens of well filled bee hives of his own.

The reverse side of the pioneer's life was not such a pleasing picture as that already given, and was more or less covered with clouded and opaque spots, which represented many trying scenes and incidents. He realized that he was isolated and almost alone, and that he lived outside of the limits of society, with no schools for his children; that he was a long distance from mills and markets and must make sacrifices and endure many hardships, which would try his patience and require manly courage and untiring perseverance to overcome.

There were some undesirable things experienced by most new settlers, among which was the prevalence of chills and fevers, in some localities; the prairie "scratches," rattlesnakes, woodticks, and in summer time, swarms of hungry 
mosquitoes which the early settler could not keep out of his rudely constructed cabin. The pioneer's "castle" was usually a one-story building, fourteen by sixteen or eighteen feet long, with two small windows, a door, and a stick and mud chimney. This limited space frequently served for kitchen, dining and sleeping rooms, and the place where "Nancy Jane received her best fellow on Sunday nights." The outbuildings were rudely constructed stables, covered with prairie hay, and the domestic animals usually had but little shelter from the piercing winds and chilly snow storms of midwinter.

The writer has adverted to some incidents, in the foregoing sketch of pioneer life, which came under his personal observation and experience, though not among the earliest settlers, having come to the county in the early part of May, 1844 .

Bertram Township, Linn Co., Iowa, July, 1899.

Snow Stokm.-One of the severest snow storms ever known in Northern Iowa, visited this vicinity last week. Snow fell to the depth of about twelve inches, but most of it lies in drifts varying from two to six feet in height. The roads were badly blockaded, and our mails were delayed somewhat, but most of our lines of stages are now making trips with their accustomed regularity.-Ft. Dodge Republican, December 23, 1863.

Hon. J. A. Kasson, after remaining two or three days with his old friends, left on the stage yesterday morning for Washington city. His numerous acquaintances here were much gratified to see him. He is a gentleman whom we are willing to trust as a representative of Iowa anywhere on the two continents.-Daily State Register (Des Moines), January 18, 1862. 
Copyright of Annals of Iowa is the property of State of Iowa, by \& through the State Historical Society of Iowa and its content may not be copied or emailed to multiple sites or posted to a listserv without the copyright holder's express written permission. However, users may print, download, or email articles for individual use. 